\title{
Can geopolitics derail the pandemic treaty?
}

\author{
During the pandemic, the world has experienced how the geopolitics of global health have \\ immediate, ruthless repercussions for the lives and livelihoods of billions, say llona Kickbusch
} and Anna Holzscheiter. The challenge of a pandemic treaty negotiation process is to be
responsive to these interconnected levels of geopolitics

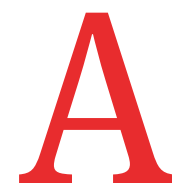

key challenge in negotiating a pandemic treaty will be to overcome the two big political divides in global health. The first is the scandalous health inequity that the global south is no longer willing to accept. The second is the intense state competition between big powers. Instead of cooperating on a health issue that is global and affects every country and every individual, the world fell apart. The pandemic came at a time when geopolitical rivalry and mistrust had picked up speed and resulted in a further weakening of support for the multilateral system, often for different reasons. As conflicts between China and the US became more pronounced, this not only affected and initially weakened the World Health Organization, but also made agreements at the G7 and G20 near impossible, rather than bringing competing countries together in a multilateral context. It also obstructed progress to achieve vaccine equity.

\section{Changed dynamics}

Does this inability to make decisions responding to urgency reflect more than a "phase" of weak multilateralism or a lack of political will in leaders? Analysts studying the politics of climate change ${ }^{1}$ have argued that a new power dynamic is emerging and already manifesting itself in G20 and the COP26 negotiations. Geopolitics today is not about a new cold war but about establishing a new technological order, in which claims to power are inseparable from technology, science, ownership of data, and authority in the digital world ${ }^{2}$-bringing with them new dimensions of inequality. Pandemic response is not only about health security and crisis governance, but also-like climate change-a field marked by innovation, technology, and multiple corporate interests, for which no international rules exist. Global health, with its strong base in science, technology, and data, is now part of a reassessment of how world politics should be organised, according to which principles and values it should proceed, which actors should be involved, and which hierarchy of institutions should apply. This makes it difficult to agree on a way forward.

The lack of global solidarity has made vaccine inequity the defining challenge in global health. Those already hit hardest by global inequity in access to healthcare now face additional barriers in the realisation of their right to health as they cannot gain access to vaccines, therapeutics, and diagnostics. No wonder civil society organisations call for a "decolonisation of global health" ${ }^{3}$ and fight for a waiver of TRIPS (Trade-Related Aspects of Intellectual Property Rights). For the global south to accept a binding treaty, it would need to address the concerns of low and middle income countries, such as equity and human rights, the sharing of knowledge, technology and innovation, and the financing of global public goods for health. ${ }^{4}$ This not only meets with opposition from some states but also from major interests in the private sector.

Together with the climate emergency, the pandemic is one of the most colossal global events of our lifetimes-but politics has not risen to the challenge. Major powers did not support WHO, the international agency that was created to ensure the highest possible level of health for all peoples and to act as the coordinating and directing authority in international health, particularly in health emergencies. Rather than inspiring a collective response to a public health emergency of international concern (PHEIC), the pandemic reinforced competitiveness between countries. Controlling the virus became a matter of achieving systems advantage, practising vaccine nationalism, controlling supply chains, and exploiting strategic geopolitical opportunities.

The pandemic magnified national conflicts and challenges, such as the seminal election of Trump versus Biden (which it seems the virus decided), and in China the country's international status and the domestic power of President Xi. In many countries the crisis turned into a political test for the sitting governments, driven by league tables that ranked countries according to their pandemic response. Lack of concern in the global north about vaccine inequity remains a constant.

The European Union made use of the G20 Italian presidency in 2021 to expand its geopolitical role in health, and took the lead in financing new mechanisms, including Access to COVID-19 Tools Accelerator (ACT-A) and Covax. It picked up a proposal from the Global Preparedness Monitoring Board (GPMB) in 2019 to create a "framework" for pandemic preparedness and response. Charles Michel, the president of the European Council, called on countries in November 2020 to adopt a "pandemic treaty" under the auspices of the WHO constitution. Two key motivations drove the proposal: opting for an approach that reflects the rule of law as one of the fundamental values of the EU and offering a counter proposal to all the suggestions to move pandemic response away from WHO.

The immediate intent was for member states of WHO to quickly agree to negotiate such an instrument after a decision at the World Health Assembly (WHA) in May 2020, but this sense of urgency was deferred to a special session of the WHA in November 2021, not least because of pressure from the US. It left open to question the extent to which a new US administration was willing to strengthen WHO. The Biden administration proclaimed that it was back to take leadership in global health, but other countries no longer automatically accepted a leadership role modelled on the past. Medium sized powers and coalitions of small states from the global south seek a much greater say-an issue that will come to the fore in the G20 presidencies of Indonesia (2022) and India (2023). Additionally, many African voices clearly will only accept a pandemic treaty if it addresses key equity issues. ${ }^{5}$

\section{The response gap}

The covid-19 pandemic has undeniably exposed gaps in global health governance, in particular the limitations of the exist- 
ing rule book-the International Health Regulations (IHR)-and the institutional capacities of WHO. Stronger enforcement, oversight power, and possibly sanctioning are needed to enhance reporting, transparency, and international exchange of data, and to ensure global cooperation in the distribution of vaccines and other resources. ${ }^{6}$ Many countries proposing a pandemic treaty hope that a new instrument would help break the cycle of panic and neglect and close the political gap by elevating action to higher levels of authority and oversight than is the case with the IHR.

Mechanisms to better work together, respond rapidly, and create more equity were laid out early by WHO, with many global health organisations joining forces in ways they had never done before: WHO declared a PHEIC on 30 January 2020 and by April 2020 had established a ground breaking global collaboration to accelerate development, production, and equitable access to covid-19 tests, treatments, and vaccines: ACT-A. Covaxthe vaccine pillar of ACT-A-was created to accelerate the development and manufacture of covid-19 vaccines, and to guarantee fair and equitable access for every country in the world through a new mechanism for pooling risk. In May 2020, WHO and partners launched the COVID-19 Technology Access Pool to facilitate timely, equitable, and affordable access to covid-19 health products by boosting their supply. Many of the key parties (apart from the EU) were absent from these developments.

When a vaccine became available in record time, the political gap was turned into a vaccine distribution gap. The world did not came together to launch a truly global initiative during the vaccine development phase nor when production became possible and the need for fair distribution was paramount. Covax was left out in the cold. The EU, which had started its global foray with such determination, failed in the equitable sharing of vaccines and intellectual property. And positioning continued: in September 2021 the US president called a vaccine summit at the UN General Assembly, ${ }^{7}$ and in October 2021 the Chinese president at the G20 meeting called for a global vaccine cooperation action initiative. ${ }^{8}$

The target now is to vaccinate at least $40 \%$ of the population of all countries by the end of 2021 and at least $70 \%$ by mid 2022, as well as the extension of the ACT-A mandate. But the G20 says little on how this will be achieved, especially regarding fair financing. The G20 did not adopt a proposal to establish a new facility to close the financing gap, as proposed by the US and Norway, ${ }^{9}$ but decided to create a Health-Finance Task Force to be jointly chaired by the 2021 and 2022 G20 presidencies. The task force will report to health and finance ministers in early 2022 and will be assisted by a secretariat housed at WHO, with the support of the World Bank. Many interpreted this, again, as a political failure, but it must also be seen through geopolitical eyes as the rejection by some G20 members of yet another new mechanism housed at the World Bank and close to US control. The approved approach now links the task force to WHO, thus respecting and supporting its constitutional role within the multilateral system rather than going down the road of ever more institutional fragmentation.

\section{A new pandemic treaty and changes in power constellations}

The concomitance of a global crisis that goes far beyond a health and an ongoing reconfiguration of geopolitical power makes predicting the outcome of pandemic treaty negotiations difficult. Would a treaty help to overcome geopolitical divides between the US and China, between the global north and south, between liberal democracies and alliances of populist, often illiberal political systems? Or will the initiative fail precisely because of these divides? Scholarly analysis of decades of international treaty making has helped to identify three factors that make successful global institution building likely: firstly, strong international or global interdependency reflected in collective action; secondly, the financial and ideological support of powerful states or groups of states; and thirdly, shared values and norms, such as belief in multilateralism, global solidarity, and human rights.

The least problematic of these three "ingredients" seems to be the acknowledgment that pandemics are situations of extreme global interdependency, ripe with collective action problems-that is the dependency of collective health security on effective pandemic preparedness and response, public health, and economic policies everywhere. The many proposals on institution building surrounding covid19 result from the recognition that pandemics are a collective problem and that multilateral or global cooperation on prevention and control of pandemics is needed. The larger group of liberal, multilateralist countries that are pushing for a pandemic treaty share a solid fundament of values and norms. Support for the treaty from low and middle income countries, in contrast, is dependent on richer countries delivering on their promises for greater equity, sharing, and access as part of the security equation.

\section{Replacement or repair?}

Beyond the power struggle between the US and China, however, the reactions of some groups-BRICS (Brazil, Russia, India, China, and South Africa), alliances of small state and medium sized powers, and nonstate parties-towards the pandemic treaty initiative reveal many lines of division. Powerful states (US, Russia, China) must not obstruct negotiations, even if they do not intend-or are unsure if they are able - to ratify, and poorer countries must be willing to give a treaty the benefit of the doubt. The results of the Working Group on Strengthening WHO Preparedness and Response to Health Emergencies (WGPR) at WHO highlight this direction, and call for negotiation of a new instrument as well as strengthening the IHR (2005).

Without doubt, the institutional landscape of contemporary global health governance is the result of ongoing institutional experimentation beyond longstanding intergovernmental cooperation through WHO or the World Bank. Since the early 2000s, global health has offered a fertile environment for growing partnerships and alliances between public institutions and the private sector. At a time when WHO was, once more, believed to be excessively bureaucratic, slow, and inefficient, the creation of new global health partnerships was celebrated as the result of innovation and an instrument of greater efficiency. Yet, in that very period, WHO proved its constitutional role by adopting two major treaties: the Framework Convention on Tobacco Control and the revision of the IHR. The increasing number of other global health bodies created another problem-a weakening of the only global health institution able to set norms and standards and negotiate binding treaties.

The question of innovation as replacement versus innovation as renovation is of course much too simple, but it will, most certainly, inform negotiations for a new pandemic treaty. Global health has very little binding international lawand thus states are unwilling to surrender sovereignty. Particular sensitivity should be shown towards governments advocating replacement and the creation of new 
structures. Some argue that supporting a new global treaty is a smokescreen to deflect from the domestic failure of some countries in their pandemic preparedness and response. ${ }^{10}$ Many civil society organisations have legitimate concerns that the pandemic treaty project will turn the attention of the international community away from the historically strong opposition towards patent monopolies on lifesaving drugs and the unprecedented collective call for a TRIPS waiver. ${ }^{11}$ Others reject the treaty because they fear it would make WHO more powerful. They have been de-funding the regular budget of WHO and, instead, finance and rely on a highly fragmented and often poorly synchronised institutional patchwork. ${ }^{3}$ While some want a treaty to strengthen WHO, others ask if expectations are too high: would a new treaty really be able to plug the regulatory gaps exposed by covid-19 if the IHR had not been implemented over the past 15 years? And finally-would a treaty really help to close the equity and power gap between high income countries and those with low or middle incomes?

The scramble for a seat at the negotiating table This leads to the question that consumes any treaty exercise: is there a legal vacuum that needs to be filled by a new agreement or is there simply a crisis of implementation and oversight? And how does a new agreement relate to existing international law? The shape of the treaty as a framework convention is emerging, and extending this intergovernmental instrument towards non-state parties, both in terms of their rights and their responsibilities, will be challenging.

The geopolitical power struggles in which the pandemic treaty project is embedded will be reflected, without doubt, in the varying degrees of enthusiasm with which WHO member states engage with the negotiation process. Non-state actors already began their scramble for participation in the treaty making process the moment that EU President Charles Michel launched his initiative. ${ }^{12}$ Against the backdrop of diversified global health, in which power relationships between wealthy nations (mostly in the global north) and low and middle income countries (mostly in the global south) have shifted, and in which non-state actors yield considerable financial, agenda setting, and normative power, the extent of the involvement by representatives of civil society, science, and corporate interests in the drafting of the treaty is destined to be hotly debated. ${ }^{13}$
When Trump withdrew the US from WHO, the EU worked towards filling the power void, and it is clear that trust in the US is not yet fully re-established. At the same time, countries that have been particularly disillusioned by an EU that failed them in terms of equity and access will be less motivated to engage in the treaty making process. It is therefore of prime importance that Indonesia and India chair the G20 during a negotiation phase in 2022 and 2023.

\section{Conclusion}

A unique opportunity has emerged to change the parameters of global cooperation and international authority on pandemic preparedness and response through a pandemic treaty. The ongoing struggles of many countries to contain covid-19 despite high vaccination rates might be instrumental in keeping up momentum to strengthen and expand international rules on pandemic preparedness and response. As we write, WHO has stated that Europe is again the epicentre of the pandemic. The discussions of a new pandemic treaty also coincide with other important reform discussions-a revision of the IHR and a revision of international patent protection rules under the WTO TRIPS agreement. In the face of crises in health, economy, and governance-and considering the weak legalisation of global health, an extended negotiation process that takes place in parallel (as proposed by the WGPR) could lead to complications and be a burden to many member states. Such is the cost of a geopolitical deal. Countries can discuss or even combine different paths, but they must not drop the issue during a geopolitical standoff, leaving the world without a potent international instrument when the next pandemic strikes.

The tectonic shifts and dislocations, from governmental to non-governmental actors, from traditionally great powers to emerging powers, and from the global north to the south suggest that new perspectives on geopolitics are needed that go beyond the traditional study of macro power struggles between sovereign states. At a minimum, the notion of geopolitics needs to include the power of corporations and private foundations, their strategies to broaden their spheres of influence through innovation and technology, and their roles not only as shapers of international rules but also as the bearers of responsibility under international law. More broadly still, the geopolitics of global health must include the geopolitics of the intimate ${ }^{14}$ and the trust of citizens in their governments and in international institutions. With the pandemic, the world has experienced how the geopolitics of global health have immediate, ruthless repercussions for the lives and livelihoods of billions. The challenge of a pandemic treaty negotiation process is to be responsive to these interconnected levels of geopolitics. The power politics of the few still dominate international institutions, and the expectation of the many is that the new treaty will place the life, wellbeing, and access to health of all peoples at the centre of pandemic preparedness and response.

Contributors and sources: This article was written in the framework of a project at the Global Health Centre at the Graduate Institute of International and Development Studies (Geneva) to support the ongoing discussion on a pandemic treaty through independent information on key issues.

Competing interests: We have read BMJ policy on competing interests and have the following to declare: none.

Provenance and peer review: Commissioned; externally peer reviewed.

This article is part of a collection of articles on a global pandemic treaty. The collection was proposed by the Global Health Centre at the Graduate Institute. The BMJ edited and made the decisions to publish the articles. Article handling and open access fees are funded by a research project at the Global Health Centre, Graduate Institute, Geneva. Kamran Abbasi and Juliet Dobson are the editors for The BMJ.

Ilona Kickbusch, professor ${ }^{1}$

Anna Holzscheiter, professor of international politics $^{2}$

${ }^{1}$ Graduate Institute of International and Development Studies, Geneva, Switzerland

${ }^{2}$ Technical University Dresden, Germany

Correspondence to: A Holzscheiter

anna.holzscheiter@tu-dresden.de

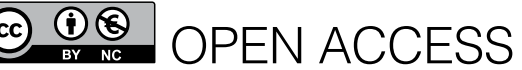

This is an Open Access article distributed in accordance with the Creative Commons Attribution Non Commercial (CC BY-NC 4.0) license, which permits others to distribute, remix, adapt, build upon this work non-commercially, and license their derivative works on different terms, provided the original work is properly cited and the use is non-commercial. See: http://creativecommons.org/ licenses/by-nc/4.0/.

\section{D) Check for updates}

1 Charbonnier P. For an ecological realpolitik. https:// www.e-flux.com/journal/114/365035/for-anecological-realpolitik/.

2 Macaes B. A new technological order. https:// policyexchange.org.uk/a-new-technological-order/ Ramakrishnan N. Why India must speak up against the new pandemic treaty proposal at the WHO. The Wire. 24 May 2021. https://thewire.in/health/whyindia-must-speak-up-against-the-new-pandemictreaty-proposal-at-the-who

4 Svet Lustig V. Global health is in disarray-but is a pandemic treaty the way out? Health Policy Watch. 23 April 2021. https://healthpolicy-watch.news/ global-health-is-in-disarray-but-is-a-pandemic-treatythe-way-out 
5 Olatunbosun-Alakija A. Unless we address the inequity in global health, then the world will not be prepared for the next pandemic. BMJ 2021:375:n2848. PubMed doi:10.1136/bmj.n2848

6 Gostin LO, Halabi SF, Klock KA. An international agreement on pandemic prevention and preparedness. JAMA 2021;326:1257-8. PubMed doi:10.1001/jama.2021.16104

7 Global COVID-19 Summit: Ending the pandemic and building back better. https://www.whitehouse.gov/ briefing-room/statements-releases/2021/09/24/ global-covid-19-summit-ending-the-pandemic-andbuilding-back-better/

8 Xi proposes global vaccine cooperation action initiative. Xinhuanet. 30 October 2021. http://www. news.cn/english/2021-10/30/c_1310280156.htm.
9 Government of Norway. A 100-day proposal for reviewing, designing and launching the establishment of a financial intermediary fund for global health security and pandemic preparedness. 2021. https://www.regjeringen.no/contentassets/ b08d6547c19343c5970cfb173ba960a5/diallog_ preparedness.pdf

10 Tomlinson C. The politics and promise of a pandemic treaty. New Frame. 16 April 2021. https://www. newframe.com/the-politics-and-promise-of-apandemic-treaty/

11 Ramakrishnan N. The pandemic treaty proposal expands global health inequities. Peoples Dispatch. 19 November 2021. https://peoplesdispatch. org/2021/11/19/the-pandemic-treaty-proposalexpands-global-health-inequities/
12 Blom IM, Campos LN, El Amine Youcef Ali M, et al. Youth versus pandemics: the role of future generations in the pandemic treaty. Lancet Glob Health

2021;9:e1361-2. PubMed doi:10.1016/S2214109X(21)00307-7

13 World Health Organization. Proposed modalities of engagement for relevant stakeholders. 2021. https:// apps.who.int/gb/wgpr/pdf_files/wgpr1/WGPR1_6en.pdf

14 Barabantseva E, Ní Mhurchú A, Peterson VS. Introduction: engaging geopolitics through the lens of the intimate. Geopolitics 2021;26:343-56 doi:10. 1080/14650045.2019.1636558.

Cite this as: $B M / 2021 ; 375: \mathrm{e} 069129$

http://dx.doi.org/10.1136/bmj-2021-069129 